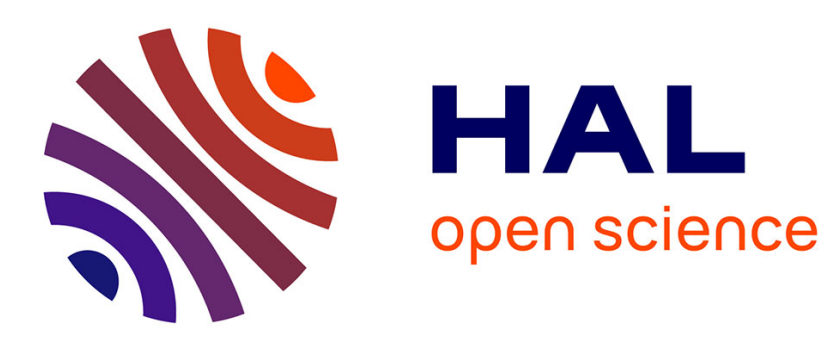

\title{
Lactobacillus helveticus: Strain typing and genome size estimation by pulsed field gel electrophoresis
}

\author{
Sylvie S. Lortal, A. Rouault, Stéphane Guezenec, M. Gautier
}

\section{To cite this version:}

Sylvie S. Lortal, A. Rouault, Stéphane Guezenec, M. Gautier. Lactobacillus helveticus: Strain typing and genome size estimation by pulsed field gel electrophoresis. Current Microbiology, 1997, 34, pp.180185. hal-02694639

\section{HAL Id: hal-02694639 \\ https://hal.inrae.fr/hal-02694639}

Submitted on 1 Jun 2020

HAL is a multi-disciplinary open access archive for the deposit and dissemination of scientific research documents, whether they are published or not. The documents may come from teaching and research institutions in France or abroad, or from public or private research centers.
L'archive ouverte pluridisciplinaire HAL, est destinée au dépôt et à la diffusion de documents scientifiques de niveau recherche, publiés ou non, émanant des établissements d'enseignement et de recherche français ou étrangers, des laboratoires publics ou privés. 


\title{
Lactobacillus helveticus: Strain Typing and Genome Size Estimation by Pulsed Field Gel Electrophoresis
}

\author{
Sylvie Lortal, Annette Rouault, Stéphane Guezenec, Michel Gautier \\ INRA, Laboratoire de Recherches de Technologie Laitière, 65 rue de St Brieuc, 35042 Rennes Cedex, France
}

Received: 13 July 1996 / Accepted: 12 September 1996

\begin{abstract}
Genomic DNAs of 22 strains of Lactobacillus helveticus of various geographical origins were analyzed by pulsed-field gel electrophoresis. Two endonucleases, SmaI and SgrAI, of the 19 tested produced DNA fragments useful for strain comparison. With the endonuclease SmaI, a characteristic restriction pattern was identified for 18 of the 22 strains. The percentage of similarity (Dice coefficient) between the profiles varied between $26 \%$ and $100 \%$, and clustering was accomplished by using the unweighted pair group method with arithmetic averages (UPGMA). For the strains showing identical profiles, the high genomic similarity was confirmed when the endonuclease SgrAI was used instead of SmaI. From summation of SmaI and SgrAI fragments from three L. helveticus strains (CNRZ 241, CNRZ 303, and CIP 57.15), the genomic length was estimated at ca. 1.85-2.0 Mb.
\end{abstract}

Lactobacillus helveticus is used extensively in the manufacture of Swiss type cheeses and Grana Padano [1, 23], and it has also been found in Bulgarian sour milk [5]. Several technological properties of that species have been studied, such as sugar fermentation, proteolytic and lipolytic activity, autolysis, and aroma production [22, 24]. An efficient strain typing tool would be useful for the preparation of well-defined starters, as well as to identify one particular strain in complex ecosystems like cheeses. Until now, only a few typing methods have been proposed for lactobacilli, and in particular for L. helveticus [7], including M13 DNA fingerprinting [16] and ribotyping [18]. These two methods have been applied only to one strain of L. helveticus (ATCC 15009), and their efficiency in L. helveticus strain differentiation has not been checked by these authors. Previously, by comparing the phenotypic and genotypic characteristics of six strains of L. helveticus, Manachini and Parini [14] concluded that fingerprinting of total DNA by the restriction enzymes EcoRI, BamHI, and HindIII with conventional electrophoresis might provide a useful tool for strain differentiation in that species. Recently, the DNA fingerprinting by pulsed field gel electrophoresis (PFGE), allowing the comparison of large restriction fragments [15], has been successfully applied to strain typing of

Correspondence to: S. Lortal various lactic acid bacteria: Lactococcus lactis [11, 21], Leuconostoc oenos [10], Lactobacillus acidophilus group [19], Lactobacillus plantarum [4], and Streptococcus salivarius subsp. thermophilus [3]. In this paper, we describe the efficiency of PFGE of SmaI and SgrAI digests for L. helveticus strain differentiation. Moreover, the genome size of that species has been estimated in this way.

\section{Materials and Methods}

Bacterial strains and growth conditions. The strains used are listed in Table 1 . They were stored at $-70^{\circ} \mathrm{C}$ in MRS [6] supplemented with glycerol $(15 \% \mathrm{wt} / \mathrm{vol})$ and grown at $43^{\circ} \mathrm{C}$ in MRS broth.

Genomic DNA preparation and pulsed field gel electrophoresis. An overnight culture of $L$. helveticus was diluted (1/100) in fresh MRS broth and grown at $43^{\circ} \mathrm{C}$ to an $\mathrm{OD}_{650}$ of 0.3 (cellular dry weight $=0.03$ $\mathrm{mg} / \mathrm{ml})$. The cells from $5-\mathrm{ml}$ samples of the culture were harvested for $10 \mathrm{~min}$ in a centrifuge $(8000 \mathrm{~g})$, washed once in $5 \mathrm{ml}$ of TES buffer, and suspended in $400 \mu \mathrm{l}$ of $50 \mathrm{~mm}$ EDTA. The agarose blocks were prepared as described previously [12] with one modification: the temperature of agarose fusion used was $60^{\circ} \mathrm{C}$ instead of $45^{\circ} \mathrm{C}$. The agarose blocks containing the purified DNA were equilibrated overnight in the restriction endonuclease digestion buffer at $4^{\circ} \mathrm{C}$, after which they were transferred to $250 \mu \mathrm{l}$ fresh digestion buffer containing 15 units of SmaI endonuclease or 25 units of SgrAI endonuclease (Boehringer, Mannheim, Germany). For the other enzymes tested, a quantity of 20 units was used. The blocks were incubated overnight at $25^{\circ} \mathrm{C}$ for $\mathrm{SmaI}$ and at $37^{\circ} \mathrm{C}$ for $\mathrm{SgrAI}$. Pulsed field electrophoresis was performed on a Biorad CHEF DRII electrophoresis cell. Samples were electrophoresed through 
Table 1. Origin of the strains

\begin{tabular}{|c|c|c|c|c|}
\hline Strain & Designation(s) in other collection(s) & Source & Country & Year of isolation \\
\hline CNRZ $32^{a}$ & & Artisanal starter, Comté & France & 1960 \\
\hline CNRZ $223^{\mathrm{T}}$ & ATCC 15009, CIP 103146, NCDO 2712 & Emmental & Switzerland & $<1919$ \\
\hline CNRZ 241 & & Artisanal starter, Comté & France & 1963 \\
\hline CNRZ 243 & & Artisanal starter, Comté & France & 1963 \\
\hline CNRZ 303 & & Artisanal starter, Comté & France & \\
\hline CNRZ 414 & & Koumis (cow milk) & URSS & 1971 \\
\hline CNRZ 493 & & Commercial starter, Emmental & Finland & 1978 \\
\hline CNRZ 834 & NZ DRI 5001 & Emmental & Switzerland & $<1918$ \\
\hline CNRZ 1094 & NCDO 766 & Starter, Emmental & Finland & $<1955$ \\
\hline CNRZ 1102 & & Artisanal starter, Grana Padano & Italy & 1988 \\
\hline CNRZ 1110 & (IL 590) & Commercial starter & France & 1970 \\
\hline CIP $57.15^{b}$ & ATCC 12046 , NCDO 1829, NCIB 8333 & & & 1956 \\
\hline ISLC $5^{c}$ & & Artisanal starter, Grana Padano & Italy & \\
\hline NCFB $384^{d}$ & & Rennet & France & $<1954$ \\
\hline $\mathrm{B} 832^{e}$ & & & Netherlands & \\
\hline $\mathrm{A}^{f}$ & & Industrial starter, Emmental & France & \\
\hline B & & Industrial starter, Emmental & France & \\
\hline $\mathrm{C}$ & & Industrial starter, Emmental & France & \\
\hline $\mathrm{D}$ & & Industrial starter, Emmental & France & \\
\hline $\mathrm{E}$ & & Industrial starter, Emmental & France & \\
\hline $\mathrm{F}$ & & Industrial starter, Emmental & France & \\
\hline $\mathrm{CP} 615^{g}$ & & & Japan & \\
\hline
\end{tabular}

${ }^{a}$ CNRZ, Centre National de Recherche Zootechnique, Collection, 78352 Jouy-en-Josas, France.

${ }^{b}$ CIP, Collection de l'Institut Pasteur.

${ }^{c}$ Kindly provided by E. Neviani, Istituto Sperimentale Latiero-Caesario.

${ }^{d}$ NCFB, National Collection of Food Bacteria.

${ }^{e}$ Kindly provided by the Nizo Institute, Netherlands.

${ }^{f}$ Industrial strains, confidential origin.

${ }^{g}$ Kindly provided by Dr. Yamamoto, Japan.

$1 \%$ (wt/vol) agarose gels (ultrapur, Gibco-BRL, Paisley, Scotland), in a running buffer ( $45 \mathrm{~mm}$ Tris, $45 \mathrm{~mm}$ boric acid, $1 \mathrm{~mm}$ EDTA, pH 8.0) at $200 \mathrm{~V}$ and at $14^{\circ} \mathrm{C}$ with pulsed times and total run time indicated in the text. The photographs of the gels were scanned with a XRS laser densitometer, and the image was analyzed by the Bio-Image system (Millipore). The $\%$ of similarity $[\mathrm{S}(\%)]$ (commonly referred to as the Dice coefficient) was calculated for each pair of $\mathrm{A}$ and $\mathrm{B}$ patterns according to the equation $\mathrm{S}(\%)=\left[2 \times \mathrm{N} / \mathrm{N}_{\mathrm{A}}+\mathrm{N}_{\mathrm{B}}\right] \times 100$, where $\mathrm{N}$ is the number of matched bands, $\mathrm{N}_{\mathrm{A}}$ and $\mathrm{N}_{\mathrm{B}}$ the number of bands in pattern $\mathrm{A}$ and $\mathrm{B}$ respectively. Clustering was accomplished by using the unweighted pair group method with arithmetic averages (UPGMA) and a standard deviation of $3.3 \%$.

Determination of the genome size. The SmaI and SgrAI restriction patterns (obtained with an increasing pulse time of 3-40 s, for $22 \mathrm{~h}$ ) were used for the genome size determination of three different strains (CNRZ 241, CNRZ 303, and CIP 57.15). The following markers were loaded on the gels: concatemers $\lambda$ (Boehringer) as well as a marker named TL that has been developed in our laboratory. The TL was obtained by cutting the genomic DNA of a particular propionibacteria strain with the restriction enzyme XbaI. The 13 largest fragments were regularly spaced in the profile, allowing their use as marker. The size of each fragment has been determined $(2,6.2,21.3,45.4,60.8,78,108,154,217$, 257, 278, 460, and $530 \mathrm{~kb}$; A.F. de Carvalho, personal communication) by comparison with three other commercial markers: CHEF DNA (Biorad), $\lambda$ DNA-PFGE (Pharmacia), and DNA size standard yeast chromosomal (Biorad). The fragments 2 and 6.2 are often not visible.

\section{Results}

Restriction endonuclease digestion patterns of $L$. helveticus ATCC 12046 genomic DNA. The DNA base composition of L. helveticus has been reported to be in the range of $37-40 \mathrm{~mol} \% \mathrm{G}+\mathrm{C}[8,9]$. The genomic DNA of L. helveticus ATCC 12046 was digested by 19 endonucleases with recognition sequences that are rich in $\mathrm{G}+\mathrm{C}$ and/or including CTAG, CGG, and CCG, sequences that have been reported to be rare in prokaryotes DNA [15]. ApaI, SacI, NotI, SfiI, SmaI, NarI, AvaII, MspI, BglI, KspI, StyI, HpaII, NaeI, HaeII, CfoI, XhoI, HindIII, SgrAI, RsrII were assayed under the following electrophoresis conditions: pulse time $1-13 \mathrm{~s}$ for $20 \mathrm{~h}$, with the buffers and concentrations indicated by the suppliers. The endonucleases HindIII, AvaII, BglI, KspI, StyI, HpaII, NaeII, HaeII, CfoI, XhoI led to a very high number of fragments below $100 \mathrm{~kb}$ and for that reason were not suitable for strain comparison or genome size determination (data not shown). By contrast, the endonucleases NotI, SacI, MspI, and SfiI produced too few fragments (data not shown). The more informative pat- 


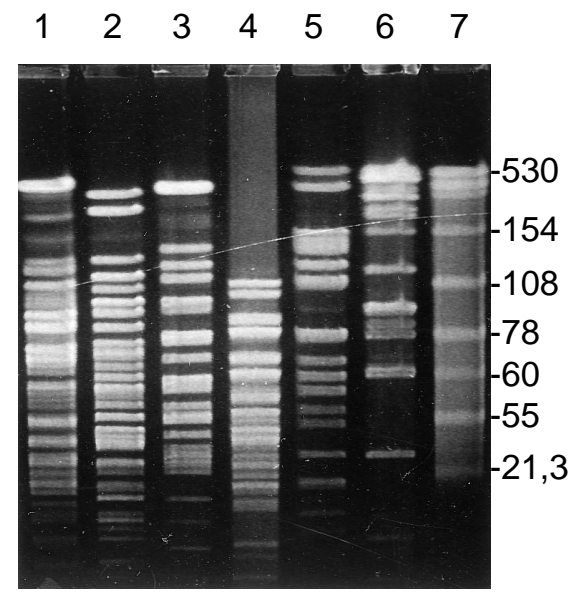

Fig. 1. PFGE patterns of several restriction enzyme digests of genomic DNA from L. helveticus CIP 57.15. Electrophoresis was performed with a pulse time ramped from $1 \mathrm{~s}$ to $13 \mathrm{~s}$ for $20 \mathrm{~h}$ at $200 \mathrm{~V}$. Lane 1, NarI; lane 2, ApaI; lane 3, SmaI; lane 4, XhoI; lane 5, SgrAI; lane 6, RsrII; lane 7, TL marker (kb indicated on the right). The enzymes SmaI and SgrAI were chosen for further optimization of the electrophoresis parameters.

terns (Fig. 1) were obtained by using SmaI, SgrAI, and $R s r$ II, and to a lesser extent ApaI. SmaI [CCC $\downarrow$ GGG] and $\operatorname{SgrAI}[\mathrm{C}(\mathrm{A}$ or $\mathrm{G}) \downarrow \mathrm{CCGG}(\mathrm{T}$ or $\mathrm{C}) \mathrm{G}$ ] were retained for further optimization of the pattern.

Optimal separation of SmaI and SgrAI digests and genome size determination. Several parameters can modify the pattern obtained with a given restriction enzyme, in particular the switch time, the agarose and buffer concentrations, the total run time, the voltage, and the temperature of the electrophoresis performed [2]. In order to improve the patterns obtained in Fig. 1, we changed the switch time and the total run time as follows: constant switch time $(5 \mathrm{~s} / 10 \mathrm{~s} / 30 \mathrm{~s})$ for $22 \mathrm{~h}$, and increasing switch time (2-13 s for $18 \mathrm{~h}$ and $22 \mathrm{~h}$; or 3-40 $\mathrm{s}$ for $22 \mathrm{~h}$ ).

For SgrAI, the more convenient patterns for strain comparison were obtained with an increasing switch time of 2-13 s for $22 \mathrm{~h}$ (Fig. 2), and for SmaI a constant switch time of $5 \mathrm{~s}$ for $22 \mathrm{~h}$ (Fig. 3). For genome size determination, and for these two endonucleases, the largest bands were better separated with an increasing pulse time of 3-40 s for $22 \mathrm{~h}$ (Fig. 4). In these pulse conditions, the molecular size of the genome was estimated by adding the size of all the restriction fragments generated by SgrAI (except for a few particularly weak bands indicated on the figure) as well as by adding the size of all the fragments generated by $S m a \mathrm{I}$. The total values ranged from $1.85 \mathrm{Mb}$ with $S m a \mathrm{I}$ patterns to $2 \mathrm{Mb}$ with SgrAI patterns (Table 2). The three strains led to very close values, and the result depended mainly on the enzyme used.

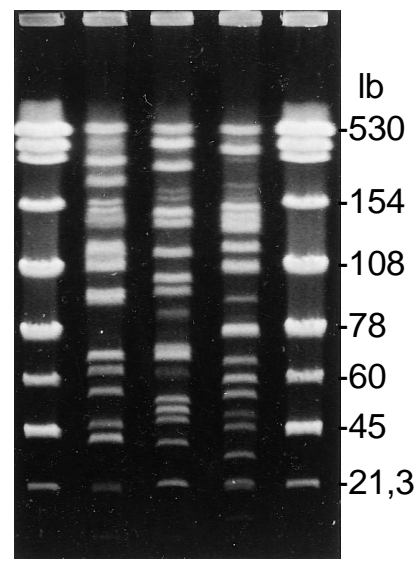

Fig. 2. PFGE patterns of SgrAI digests of genomic DNA separated with a pulse time ramped from $2 \mathrm{~s}$ to $13 \mathrm{~s}$ for $22 \mathrm{~h}$. Lanes $1 \& 5$, TL marker; lane 2, strain CNRZ 241; lane 3, strain CNRZ 303; lane 4, strain CIP 57.15 .

Comparison of SmaI restriction patterns of $22 \mathrm{~L}$. helveticus strains of various origins. When genomic DNA from 22 strains was digested by SmaI and examined by PFGE (Fig. 3), 18 different restriction patterns resulted. As shown in the dendrogram established by the average linkage method (UPGMA), the average percentage of similarity between the profiles varied from $44 \%$ to $100 \%$ (Fig. 3), and several groups (at least two) can apparently be defined. The first group is composed of the majority of the strains (18 of the 22 tested), for which the average percentage of similarity was higher than $50 \%$. A second distinct group was constituted by four less related strains: CP615 from Japan, B832 from the Netherlands, and two industrial strains (B and E) from France. Such a dendrogram should now be confirmed by another genomic strain typing method, in order to establish whether these four strains are really less related.

The genomic DNA of the strains showing $100 \%$ similarity (D \# CNRZ 32; CNRZ 243 \# CNRZ 414; CNRZ 1102 \# ISLC 5; and B \# E) were analyzed with the second endonuclease SgrAI. Again the profiles were identical, indicating that these strains were, genetically speaking, very closely related (data not shown). Regarding the industrial strains (indicated by letters), apart from strains $\mathrm{B}$ and $\mathrm{E}$ which showed identical restriction patterns, the other industrial strains A, C, D, and F were apparently not related. It could be noticed that one of them (strain D) showed 100\% similarity with the collection strain CNRZ 32.

\section{Discussion}

The restriction of genomic DNA of Lactobacillus helveticus with rare-cutting enzymes (SmaI and SgrAI) de- 


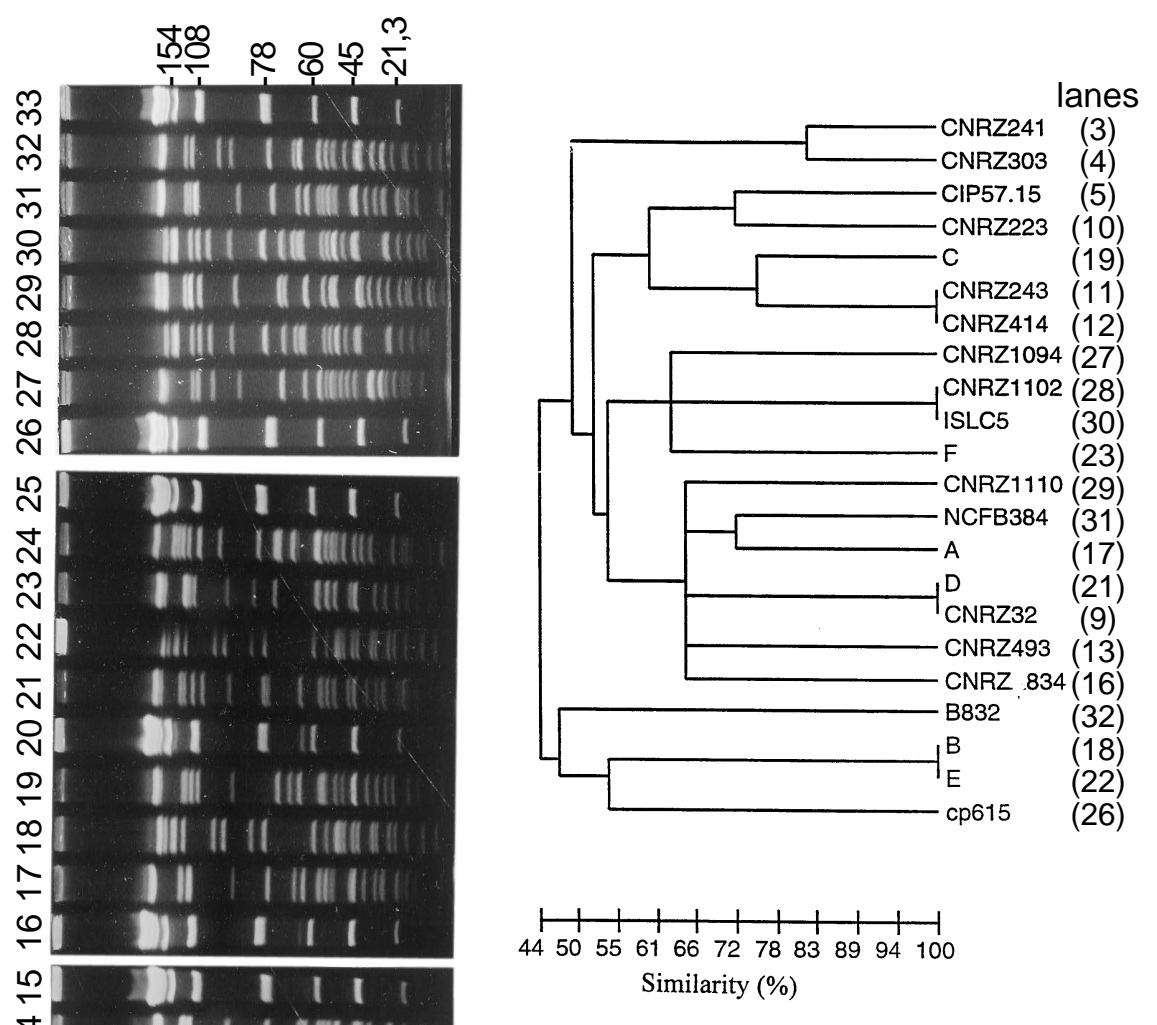

Fig. 3. Comparison of the SmaI restriction patterns of 22 L. helveticus strains. Electrophoresis was done for $22 \mathrm{~h}$ with a constant pulse time of $5 \mathrm{~s}$ at $200 \mathrm{~V}$; the dendrogram was obtained by using the UPGMA clustering method. Lanes: $1 ; 7 ; 8 ; 15 ; 16 ; 20 ; 25 ; 26 ; 33$, TL marker (kb indicated on the right and on the left); lanes 2 and 6 , concatemers lambda; the lane corresponding to each strain is indicated in the brackets. From the 22 strains tested, 18 different profiles were obtained, some strains sharing the same profile as highlighted by the dendrogram (100\% of similarity).

scribed in this work has allowed the genomic typing of 22 strains of various origins as well as genome size estimation. The fact that SmaI could be a convenient enzyme for strain typing was not surprising since similar conclusions have been drawn for species closely related, and with a similar G+C content: L. acidophilus (36\%) [19] and Listeria monocytogenes (37-39\%) [17]. By contrast, this is, to our knowledge, the first time that SgrAI was shown to be potentially as efficient as SmaI for strain typing purpose in lactic acid bacteria. Comparison of the SmaI restriction patterns indicated that the majority of strains had unique restriction patterns, and this result supports the idea that DNA restriction pattern can be a useful epidemiological tool for L. helveticus. However, strains with identical patterns were also identified, and this high genomic similarity has been confirmed by comparing the SgrAI restriction patterns of these strains, which were again identical. It could be highlighted that strains B and 
(a)

(b)
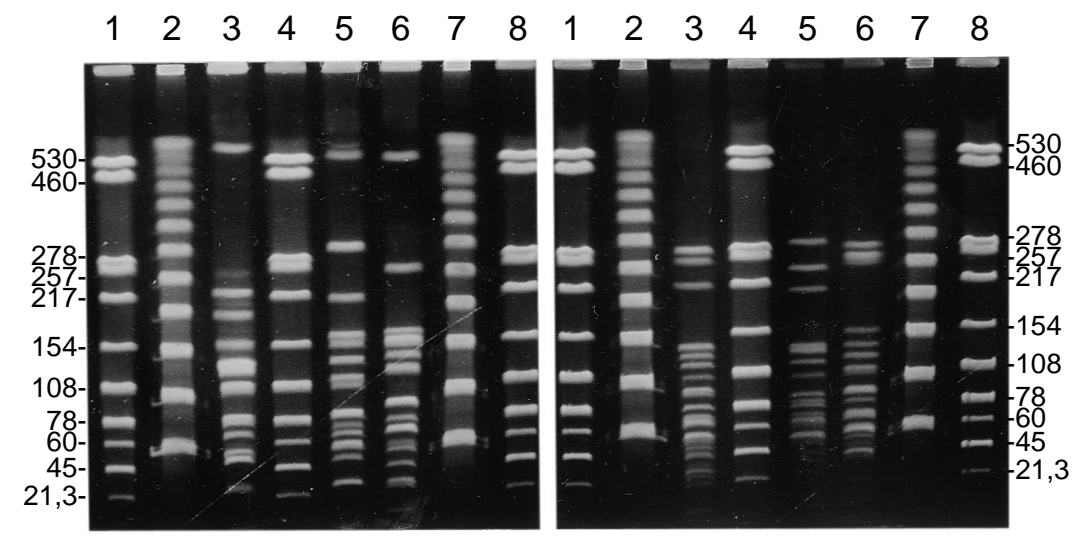

Fig. 4. For genome size determination, the largest fragments of the PFGE patterns of SgrAI (a) and SmaI (b) digests were separated with a pulse time ramped from $3 \mathrm{~s}$ to $40 \mathrm{~s}$ for $22 \mathrm{~h}$. Lanes 1,4 , and 8 , TL marker ( $\mathrm{kb}$ indicated on the left); lanes 2 and 7 , concatemers lambda; lane 3, strain CNRZ 241; lane 5, strain CNRZ 303; lane 6, strain CIP 57.15.

Table 2. Genome size (kb) of L. helveticus CNRZ 303, CNRZ 241, and CIP 57.15 estimated by summation of the SmaI or SgrAI digests shown in Fig. 4 (except for the few weak bands indicated by white stars)

\begin{tabular}{|c|c|c|c|c|c|c|}
\hline & \multicolumn{2}{|c|}{ CNRZ 241} & \multicolumn{2}{|c|}{ CNRZ 303} & \multicolumn{2}{|c|}{ CIPH 57.15} \\
\hline & SmaI & SgrAI & SmaI & SgrAI & SmaI & SgrAI \\
\hline & 271 & 594 & 282 & 540 & 268 & 529 \\
\hline & 252 & 221 & 237 & 291 & 250 & 249 \\
\hline & 217 & 188 & 205 & 208 & 240 & 163 \\
\hline & 136 & 154 & 133 & 161 & 148 & 153 \\
\hline & 125 & 132 & 127 & 150 & 131 & 145 \\
\hline & 115 & 122 & 115 & 130 & 119 & 134 \\
\hline & 102 & 109 & 100 & 113 & 107 & 120 \\
\hline & 90 & 100 & 84 & 104 & 100 & 114 \\
\hline & 86 & 80 & 79 & 80 & 86 & 87 \\
\hline & 77 & 76 & 75 & 71 & 78 & 74 \\
\hline & 69 & 66 & 68 & 64 & 66 & 66 \\
\hline & 64 & 48 & 63 & 48 & 48 & 48 \\
\hline & 48 & 46 & 47 & 46 & 47 & 47 \\
\hline & 47 & 26 & 46 & 28 & 45 & 42 \\
\hline & 46 & 16 & 41 & 15 & 40 & 26 \\
\hline & 42 & & 32 & & 34 & 23 \\
\hline & 28 & & 22 & & 25 & 18 \\
\hline & 23 & & 20 & & 20 & 15 \\
\hline & 21 & & 18 & & & \\
\hline & 16 & & 16 & & & \\
\hline Total size $(\mathrm{kb})$ & 1875 & 1976 & 1810 & 2051 & 1853 & 2054 \\
\hline $\mathrm{Nb}$ of fragments & 20 & 15 & 20 & 15 & 18 & 18 \\
\hline
\end{tabular}

E came from French dairy products and are used as dairy starters, and that strains ISLC5 and CNRZ 1102 were both isolated from Italian artisanal starter of Grana Padano. By contrast, the $100 \%$ similarity between strain CNRZ 414 isolated from Russian Koumiss and CNRZ 243 isolated from French Comté artisanal starter was more surprising. In a more general view, it would now be interesting to observe to which extent the strains showing identical restriction patterns differ in their technological properties (such as acidification, proteolysis, autolysis, phage resistance). Regarding, for example, the phage resistance, Séchaud [20] characterized the sensitivity of 65 strains of L. helveticus (including most of the strains studied in this work) towards 35 bacteriophages, and we have noted that the strains CNRZ 243 and 414 (showing identical restriction patterns) do not share identical bacteriophage sensitivity. Indeed, the strain CNRZ 243 was sensitive to four bacteriophages, whereas strain CNRZ 414 was sensitive to only one, which was, moreover, different of the four infecting CNRZ 243. Furthermore, our own unpublished observations regarding autolysis revealed a different level of activity between strains sharing identical restriction profiles. It would probably be far from evident, or maybe impossible, to predict any technological behavior from these macrorestriction profiles. To our mind, their main interest is to give the ability to follow a particular strain in a complex ecosystem. Moreover, it can be used to apply technological screenings (in general, heavy and time consuming) to a reduced number of strains, which would be chosen, not randomly, but more rationally on the basis of their genomic profiles.

With slightly different pulse conditions to separate the largest bands, the restriction patterns were used to determine the genomic length in that species. For three strains of L. helveticus, it was estimated to be near 1.85 $\mathrm{Mb}$ with the summation of SmaI fragments and near 2.0 $\mathrm{Mb}$ with the summation of SgrAI fragments. The validity of this result was difficult to assess, since the genome size of L. helveticus has not yet been estimated by another method. Nevertheless, it was in agreement with the genome size of L. acidophilus, the most phylogenetically related species of L. helveticus, which was estimated to be near $1.85 \mathrm{Mb}$ [19]. For other lactobacilli like $L$. 
plantarum and L. delbrueckii subsp. bulgaricus, it was shown to be respectively $2.8 \mathrm{Mb}$ [4] and $2.3 \mathrm{Mb}$ [13].

\section{ACKNOWLEDGMENTS}

The authors are particularly indebted to Pascal le Bourgeois and Antonio Fernandes de Carvalho for their precious advice in PFGE experiments. We sincerely thank Patrick Tailliez for providing most of the CNRZ strains. The English version of the text has been kindly revised by Jamie Davies.

\section{Literature Cited}

1. Auclair J, Accolas JP (1983) Use of thermophilic lactic starters in the dairy industry. Antonie Leeuwenhoek 49:313-326

2. Birren BW, Lai E, Clark SM, Hood L, Simon MI (1988) Optimized conditions for pulsed field gel electrophoretic separations of DNA. Nucleic Acids Res. 16:7563-7582

3. Boutrou R, Thuault D, Bourgeois CM (1995) Identification and characterization of Streptococcus thermophilus strains by pulsedfield gel electrophoresis. J Appl Bacteriol 79:454-458

4. Daniel P (1995) Sizing of the Lactobacillus plantarum genome and other lactic acid bacteria species by transverse alternating field electrophoresis. Curr Microbiol 30:243-246

5. Dellaglio F, Torriani S, Stefanova-Kondratenko M, Vlaikovska K, Ivanova P, Mustafova K (1986) Presence of Lactobacillus helveticus and an $\mathrm{L}(+)$ lactic acid former in Bulgarian sour milk. Syst Appl Microbiol 8:223-225

6. De Man JC, Rogosa M, Sharpe E (1960) A medium for the cultivation of lactobacilli. J Appl Bacteriol 23:130-135

7. Dykes GA, von Holy A (1994) Strain typing in the genus Lactobacillus. Lett Appl Microbiol 19:63-66

8. Gasser F, Mandel M (1968) Desoxyribonucleic acid composition of the genus Lactobacillus. J Bacteriol 96:580-588

9. Kandler O, Weiss N (1986) Regular, non sporing gram positive rods. In: Sneath PHA, Mair NS, Sharpe ME, Holt JG (eds) Bergey's manual of systematic bacteriology, Vol 2. Baltimore, Md: Williams and Wilkins, pp. 1208-1234

10. Kelly WJ, Huang CM, Asmundson RV (1993) Comparison of Leuconostoc oenos strains by pulsed-field gel electrophoresis. Appl Environ Microbiol 59:3969-3972

11. Le Bourgeois P, Mata M, Ritzenthaler P (1989) Genome compari- son of Lactococcus strains by pulsed-field gel electrophoresis. FEMS Microbiol Lett 59:65-70

12. Lemée R, Rouault A, Guezenec S, Lortal S (1994) Autolysis of 57 strains of dairy propionibacteria. Lait 76:241-251

13. Leong-Morgenthaler P, Ruettener C, Mollet B, Hottinger H (1990) Construction of the physical map of Lactobacillus bulgaricus. In: Abstracts of the third symposium on lactic acid bacteria, 17-21 September 1990, Wageningen, The Netherlands. FEMS Microbiol Lett 87:A28, p 19

14. Manachini PL, Parini C (1983) DNA restriction endonuclease cleavage patterns, DNA sequence similarity and phenotypical characteristics in some strains of $L$. helveticus and L. jugurti. Antonie Leeuwenhoek 49:143-152

15. McClelland M, Jones R, Patel Y, Nelson M (1987) Restriction endonucleases for pulsed field mapping of bacterial genomes. Nucleic Acids Res 15:5985-6005

16. Miteva VI, Abadjieva AN, Stefanova TzT (1992) M13 DNA fingerprinting, a new tool for classification and identification of Lactobacillus spp. J Appl Bacteriol 73:349-354

17. Moore MA, Datta AR (1994) DNA fingerprinting of Listeria monocytogenes strains by pulsed-field gel electrophoresis. Food Microbiol 11:31-38

18. Rodtong S, Tannock GW (1993) Differentiation of Lactobacillus strains by ribotyping. Appl Environ Microbiol 59:3480-3484

19. Roussel Y, Colmin C, Simonet JM, Decaris B (1993) Strain characterization, genome size and plasmid content in the Lactobacillus acidophilus group (Hansen and Mocquot). J Appl Bacteriol 74:549-556

20. Séchaud L (1990) Ph.D. thesis. University of Paris VII \& XI, France

21. Tanskanen E, Tulloch DL, Hillier AJ, Davidson BE (1990) Pulsed-field gel electrophoresis of SmaI digests of Lactococcal genomic DNA, a novel method of strain identification. Appl Environ Microbiol 56:3105-3111

22. Torriani S, Vescovo M, Scolari G (1994) An overview on Lactobacillus helveticus. Ann Microbiol Enzymol 44:163-191

23. Turner KW, Morris HA, Martley FG (1983) Swiss type cheese: II. The role of thermophilic lactobacilli in sugar fermentations. N Z J Dairy Sci Tech 18:117-123

24. Valence F, Lortal S (1995) Zymogram and preliminary characterization of L. helveticus autolysins. Appl Environ Microbiol 61:33913399 